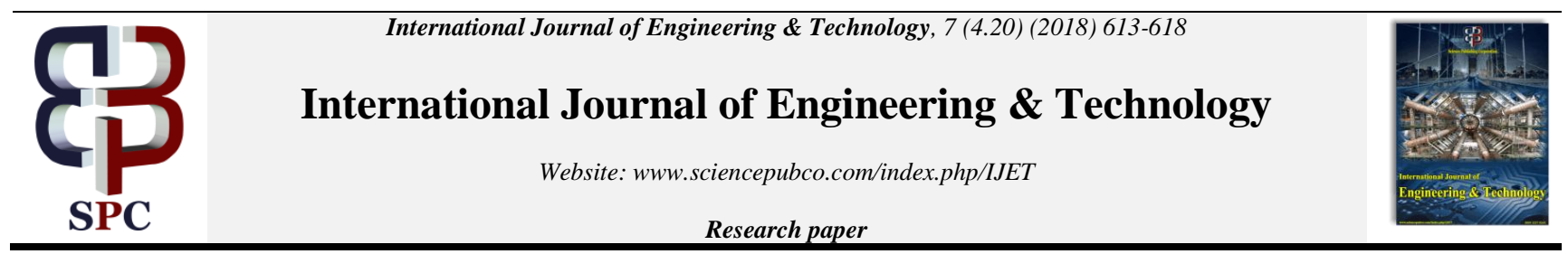

\title{
Assessment of Reinforced Recycling Aggregate Concrete Beams Under Torsional Moment
}

\author{
Kaiss F. Sarsam ${ }^{1}$, Nisreen Salih ${ }^{1}$, Mazin Hussein ${ }^{1 * 2}$ \\ ${ }^{1}$ Building and Construction Engineering Department, University of Technology, Baghdad, Iraq \\ ${ }^{2}$ Civil Engineering Department, Dijlah University, Baghdad, Iraq \\ *Corresponding author email : mazin2030@gmail.com
}

\begin{abstract}
The recycling of aggregate concrete (RAC) is the ideal solution for reducing the natural resources. The experimental works have been carried out to investigate the torsional moment behavior and the strength of RAC beams in comparison with those beams consisting of natural aggregate concrete (NAC). Nine beams were casted with different compression strengths of concrete $(25,45$, and $70 \mathrm{MPa})$, and coarse RAC of three different percentages within the full bloc of coarse aggregate in concrete mixes $(0,50$, and $100 \%)$, with the same reinforcement ratio. The properties of the concrete comprised of recycled and natural aggregates were investigated. The results showed, that the difference in the torque of first crack is less than $12.5 \%$ for RAC and NAC beams, while the difference in ultimate torque is less than 7.7\% for RAC and NAC. Also, it can be conclude that, the torsional moment performance of RAC beams is acceptable as compared to the conduct of NAC beams and the use of $\mathrm{RAC}$ is practically possible
\end{abstract}

Keywords: Reinforced concrete beam; Recycled aggregates; Torsional moment behavior

\section{Introduction}

It has been estimated that approximately 1,111,788 tons of concrete are currently demolished each year in Iraq (the Iraqi Environmental Ministry), and the waste from construction and demolition works are of huge volumes and are only increasing with time. For the environmental reason, both abstraction quantity and ultimate size of units of waste have been limited, and the growing request for concrete in the building sites great pressure on the requirement of component materials inclusive aggregate. Consideration has formerly been moved to substitutional types of aggregates like aggregate from old concrete. Reuse of aggregates from collapse concrete structures came into workout many years ago, and from initially it has been believed for its two essential environmental benefits: resolve the growing problem of waste space, and the preservation of the given natural provenance of aggregates [1]. The use of (RAC) is one such effort at the economy of raw material and is a singular method to resolve some of the disorder in civil engineering [2]. The idea of utilizing RAC is increasingly obtaining in scalability now, and investigation in this scope is making progress. When recycled aggregates square measure made of pure materials that contain over ninety-fifth of pervious concrete, the final product can typically be clean enough to satisfy specifications for concrete aggregates while not being washed [3]. Studies relating to the characteristic of recycled aggregates, and the essential properties of recycled concrete have been orderly conducted over the latest few periods, resulting in a numeral of nation making efforts at establishing recommendations supporting their use [4]. Torsion relates to one of the master structural influence besides flexure, shear and axial compression/tension that leads to further sort of brittle failure of concrete structures.

This is a leading phenomenon that must be taken into consideration when designing the different classes of reinforced concrete structures, such as spandrel beams, horizontally curved beams, spiral staircases, skew bridges, space frames and et cetera.

\section{Literature review}

Previous investigators had focused primarily on the treatment of demolished concrete, the mix design, the physical and the engineering properties. Greatest of the findings are widely studied and mentioned by Hansen [3]. The reports exposed that the applicable material advantage of RAC are mostly inferior to those of traditional concrete. RCA tend to be more porous, have higher properties of absorption, and relatively lower specific gravity than normal aggregates [4]. One of the properties of concretes made with RCA yield a lower strengths than their parallel made with normal gravel [5]. A 100\% replacement of coarse aggregate by recycled aggregate, will result in approximately a $9 \%$ decrease in compressive strength [6], and it is also estimated to yield a $15 \%$ decrease in the modulus of elasticity of recycled aggregate concrete. However, only a modicum studies have been conducted in the domain of structural behavior (behavior in flexure state, shear, torsion, etc.) [7]. There are some published research papers that deal with the use of recycled aggregates in structural behavior such as those authored by Choi et al. [8] who rated the shear strength of twenty reinforced concrete beams. These beams consisted of different span-depth ratios (1.50, 2.50, and 3.25), 
longitudinal reinforcement ratios $(0.53,0.83$, and $1.61 \%)$, and RCA replacement ratios $(0,30,50$, and $100 \%)$. Outcomes of their investigation presented that the higher RCA replacement ratio led to lower shear strength. Schubert et al. [9] studied the behavior of 14 slabs with $100 \%$ recycled coarse aggregate and reported that RAC slabs can be designed using the same design equations as for control concrete. Arezoumandi et al. [10], tested 18 beams with three different longitudinal reinforcement ratios, and the two RCA blends are various in the total of RCA permutation, (50 and 100\%). Results of that research showed that the $100 \%$ RAC beam has $11 \%$ lesser shear strength parallel with the 50\%RAC and NAC beams; but the $50 \%$ RAC and NAC beams showed comparable resistance of shear strength.

Many investigations have been reported on recycled aggregate, but the research of torsional strength with recycled aggregate are limited.

\section{Experimental work}

The experimental program based on the simile of the torsional presentation of reinforced concrete beams containing natural aggregate concrete NAC with RAC using three different level of compressive strength of concrete $(25,45$ and $70 \mathrm{Mpa})$. Also, three various proportion of coarse RAC in a full quantity of coarse aggregate in concrete mixes ( 0,50 , and $100 \%$ by weight). The same reinforcement ratio, were used as the main parameters in this analysis.

\subsection{Materials}

\subsubsection{Cement}

Ordinary Portland cement (Type I) produced in Iraq from Mass Company, was utilized in casting the specimens. It was tested as per Iraqi Standard Specification (I.Q.S. No. 5:1984) [11].

\subsubsection{Sand}

Spotless river sand is used which has fineness modulus of (2.9), specific gravity of (2.63) and sulfate content of $(0.39 \%)$ by sand weight, which is minimal than the limit of Iraqi standard specification No. 45 / 1984 [12].

\subsubsection{Coarse Aggregate}

\subsubsection{Natural Coarse Aggregate}

The coarse mixture that was applied for this survey was traditional weight crushed mixture with most size of 14 millimeter and compliant to ASTM C33-02 [14], and the Iraqi Specification No. 45/1984 [12]. Table (1) shows the physical properties of the normal coarse aggregate consistent with limit of Iraqi specification.

Table 1: Physical properties of natural coarse aggregate

\begin{tabular}{|c|c|c|}
\hline Physical properties & $\begin{array}{c}\text { Test } \\
\text { result }\end{array}$ & $\begin{array}{c}\text { Limit of Iraqi specification } \\
\text { No.5:1984 }\end{array}$ \\
\hline Specific gravity & 2.65 & - \\
Absorption & $0.7 \%$ & - \\
Crushed value & $15 \%$ & - \\
Sulfate content & $0.06 \%$ & $0.1 \%(\max )$ \\
\hline
\end{tabular}

\subsubsection{Recycled Coarse Aggregate}

Recycled coarse aggregate was obtained by hand crushing the cubes salvaged from old concrete and having a strength of (25-35) MPa. The particles in portions of various sizes were recombined to give a grading similar to that of the natural coarse aggregates that had a maximum size of (14 $\mathrm{mm}$ ) (the debris having been selected, cleaned and sieved in the laboratory). The specifications were ASTM C33-02 [13], and Iraqi Standard Specification (No. 45: 1984) [12], with analysis of the sieve of this type of coarse aggregate. Table (2) shows physical properties of recycled coarse aggregate according to the limit of Iraqi specification No.5:1984

Table 2: Physical properties of recycled coarse aggregate

\begin{tabular}{|c|c|c|}
\hline $\begin{array}{c}\text { Physical } \\
\text { properties }\end{array}$ & $\begin{array}{c}\text { Test } \\
\text { result }\end{array}$ & Limit of Iraqi specification No.5:1984 \\
\hline Specific gravity & 2.4 & - \\
Absorption & $3.6 \%$ & - \\
Crushed value & $21 \%$ & - \\
Sulfate content & $0.08 \%$ & $0.1 \%$ (max) \\
\hline
\end{tabular}

\subsubsection{Water}

Clean faucet water was used for curing and mixing of specimens.

\subsubsection{Superplasticizer}

The superplasticizer utilized during the mixing was "Glenium 51" the standard dosage of ( 0.5 liter per $100 \mathrm{~kg}$ of cement) as advocate by the manufacturer. This material classified as types (A) and (F) in ASTM C494-05 [14]. The aim of using this admixture was to improve workability and to reduce the $(\mathrm{w} / \mathrm{c})$ ratio to increase the ultimate compressive strength of concrete. The relative density of it is (1.1 $\mathrm{g} / \mathrm{cm} 3 @ 20^{\circ} \mathrm{C}$ ) and $\mathrm{PH}=6.6$.

\subsubsection{Silica fume}

Silica fume ( $\mathrm{SiO} 2)$ (very fine amorphous silica particles $<1 \mu \mathrm{m}$ ) is applied as concrete soft additive. Adding $\mathrm{SiO} 2$ fills in the spaces between cement grains because of the very small particles in a concrete mixture. The $(\mathrm{SiO} 2)$ reacts with calcium hydroxide to form additional binder material. The properties of $\mathrm{SiO} 2$, according to the manufacturer's specifications, complies with the ASTM C1240-04 [15].

\subsection{Mix proportions}

Proportions of the mix were confirmed to output reinforced concrete with a workability limit by slump values range $(5$ and $10 \mathrm{~cm})$ according to ASTM C143-00 [16]. Varied trial mixes were prepared according to the recommendations of the ACI 211.1-97 [17]. Three kinds of concrete, NAC , RAC50 (50\% by mass of NAC replaced by RAC), and RAC100 (100\% by bloc of NAC replaced by RAC), were used. The concrete mixes NAC and RAC were designed to get the same compressive strength and workability. The various mixes of material incorporating superplasticizer were obtained by rising the potion of admixture progressively and regulate the water-cement ratio. The mixture of concrete was designed to obtain cylinder strength of (25, 45 and $70 \mathrm{Mpa})$ at 28 days. Mixing details are given in Table (3). It was create that the used blend produces good workability and the uniform mix of concrete. 
Table 3: Details of mixes

\begin{tabular}{|c|c|c|c|c|c|c|c|c|c|}
\hline \multirow[t]{2}{*}{ Group } & \multirow{2}{*}{$\begin{array}{c}\text { Compressive } \\
\text { strength }\end{array}$} & \multirow{2}{*}{$\begin{array}{c}\text { Specimen } \\
\text { Notation }\end{array}$} & \multirow{2}{*}{$\begin{array}{c}\text { Cement } \\
\mathrm{kg} / \mathrm{m}^{3}\end{array}$} & \multirow{2}{*}{$\begin{array}{l}\text { Sand } \\
\mathrm{kg} / \mathrm{m}^{3}\end{array}$} & \multicolumn{2}{|c|}{ Gravel $\left(\mathrm{kg} / \mathrm{m}^{3}\right)$} & \multirow{2}{*}{$\begin{array}{l}\text { Water } \\
1 / \mathrm{m}^{3}\end{array}$} & \multirow{2}{*}{$\begin{array}{c}\text { Glenium51 } \\
1 / \mathrm{m}^{3}\end{array}$} & \multirow{2}{*}{$\begin{array}{l}\text { Silica } \\
\text { fume } \\
\mathrm{kg} / \mathrm{m}^{3}\end{array}$} \\
\hline & & & & & Normal & Recycled & & & \\
\hline \multirow{3}{*}{ N25 } & \multirow{3}{*}{$25 \mathrm{MPa}$} & $25 \mathrm{NC}$ & 350 & 700 & 1050 & - & 170 & - & - \\
\hline & & $25 \mathrm{R} 50$ & 350 & 700 & 525 & 525 & 170 & 1 & - \\
\hline & & $25 \mathrm{R} 100$ & 350 & 700 & - & 1050 & 170 & 1.6 & - \\
\hline \multirow{3}{*}{ M45 } & \multirow{3}{*}{$45 \mathrm{MPa}$} & $45 \mathrm{NC}$ & 430 & 745 & 960 & - & 185 & 5 & 50 \\
\hline & & $245 \mathrm{R} 50$ & 430 & 745 & 480 & 480 & 185 & 8 & 50 \\
\hline & & 45R100 & 430 & 745 & - & 960 & 185 & 11 & 50 \\
\hline \multirow{3}{*}{$\mathrm{H} 70$} & \multirow{3}{*}{$70 \mathrm{MPa}$} & $70 \mathrm{NC}$ & 450 & 750 & 1000 & - & 126 & 12.5 & 50 \\
\hline & & 70R50 & 450 & 750 & 500 & 500 & 126 & 16 & 50 \\
\hline & & 70R100 & 450 & 750 & - & 1000 & 126 & 19 & 50 \\
\hline
\end{tabular}

Three cylinder samples of (diameter $150 \mathrm{~mm}$, height $300 \mathrm{~mm}$ ), were cast for each kind of concrete for the determination of compressive strength testing as prescribed by ASTM C39-01[18], whilst three additional cylinders (of diameter $150 \mathrm{~mm}$, height $300 \mathrm{~mm}$ ), were cast in order to test the modulus of elasticity based on ASTM C469-02 [19],. Another three cylinders of diameter $150 \mathrm{~mm}$, height $300 \mathrm{~mm}$ were cast for the testing of splitting tensile strength, according to ASTM C496-96 [20], along with a plain concrete beam of $(100 \times 100$ $\times 500 \mathrm{~mm}$ ) loading to determine flexural strength (modulus of rupture) according to ASTM C78-02 [21]. Criterion curing process complete for all concrete segment, and the nine beams which were cured under the same situations. The properties of hardened concrete mixes are existing in Table (4) founded on normal values for three tested samples at 28 day.

Table 4: Hardened concrete properties at 28 day

\begin{tabular}{|c|c|c|c|c|c|}
\hline Group & $\begin{array}{c}\text { Specimen } \\
\text { Notation }\end{array}$ & $\begin{array}{c}\text { Compressive } \\
\text { strength } \\
f^{\prime} \text { c (MPa) }\end{array}$ & $\begin{array}{c}\text { Modulus } \\
\text { of } \\
\text { elasticity } \\
\text { Ec (Mpa) }\end{array}$ & $\begin{array}{c}\text { Splitting } \\
\text { tensile } \\
\text { strength } \\
\text { ft (MPa) }\end{array}$ & $\begin{array}{c}\text { Flexural } \\
\text { strength } \\
\text { fr (Mpa) }\end{array}$ \\
\hline \multirow{3}{*}{ N25 } & 25N.C & 25 & 26760 & 3 & \\
& 25R50 & 24 & 23572 & 2.85 & 3.4 \\
& 25R100 & 22.3 & 21830 & 2.73 & 3.14 \\
\hline \multirow{3}{*}{ M45 } & 45N.C & 46 & 35373 & 4.3 & 5.1 \\
& 245R50 & 44 & 32395 & 4.1 & 4.9 \\
& 45R100 & 42 & 29235 & 3.8 & 4.6 \\
\hline \multirow{3}{*}{ H70 } & 70N.C & 70 & 42030 & 5.5 & 6.2 \\
& 70 R50 & 68 & 39852 & 5.43 & 5.9 \\
& 70 R100 & 60 & 36566 & 4.61 & 5.1 \\
\hline
\end{tabular}

\subsection{The beams' specimen description}

The nine beams that were cast were designed with rectangular crosssectional dimensions of (100 mm width by $200 \mathrm{~mm}$ height and 1500 mm length). Beams were designed according to (ACI 318-14M) [22], with steel reinforcement of $(1 \%)$ for transverse and longitudinal reinforcement. The proportion of reinforcement incorporated in the beam was a little advanced than the lowest required (minimum total reinforcement for torsion (1\%)) [23]; (4 Ø10 mm) as longitudinal reinforcement was located around the edge of the beam and ( $\varnothing 6 @ 50$ $\mathrm{mm}$ ) for transverse reinforcement (Table 5 Steel reinforcement properties), was used as closed stirrups. The beam reinforcement and dimension as shown in Figure 1.The nine beams were sorted in three groups based on the compressive strength of concrete as (normal, middle and high) strengths of concrete. Each group consisted of three beams; one with NCA and two with RCA (50 and 100\% replacement levels of RCA).

Table 5: Steel reinforcement properties

\begin{tabular}{|c|c|c|c|c|c|}
\hline $\begin{array}{c}\text { Nominal } \\
\text { Diameter } \\
(\mathrm{mm})\end{array}$ & $\begin{array}{c}\text { Actual } \\
\text { Diameter } \\
(\mathrm{mm})\end{array}$ & $\begin{array}{c}\text { Modulus } \\
\text { of } \\
\text { Elasticity } \\
(\mathrm{MPa})\end{array}$ & $\begin{array}{c}\text { Yield } \\
\text { Stress } \\
(\mathrm{MPa})\end{array}$ & $\begin{array}{c}\text { Ultimate } \\
\text { Stress } \\
(\mathrm{MPa})\end{array}$ & Elongation\% \\
\hline 6 & 5.38 & 204700 & 510 & 675 & 11 \\
10 & 9.23 & 206000 & 490 & 654 & 13 \\
\hline
\end{tabular}

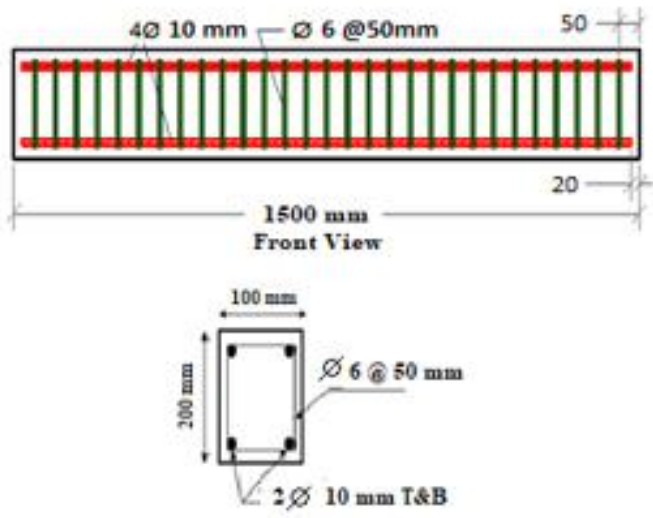

Sec. of Beam

Fig.1: Details of beam dimension and reinforcement

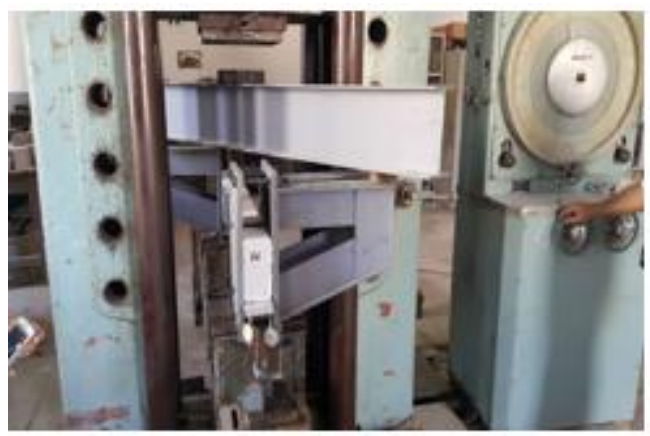

Figure 2: The testing machine and the beam setup 


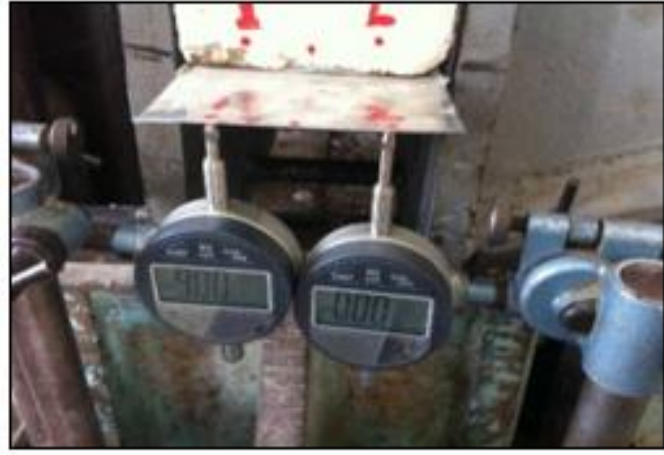

Figure 3: Digital dial gage

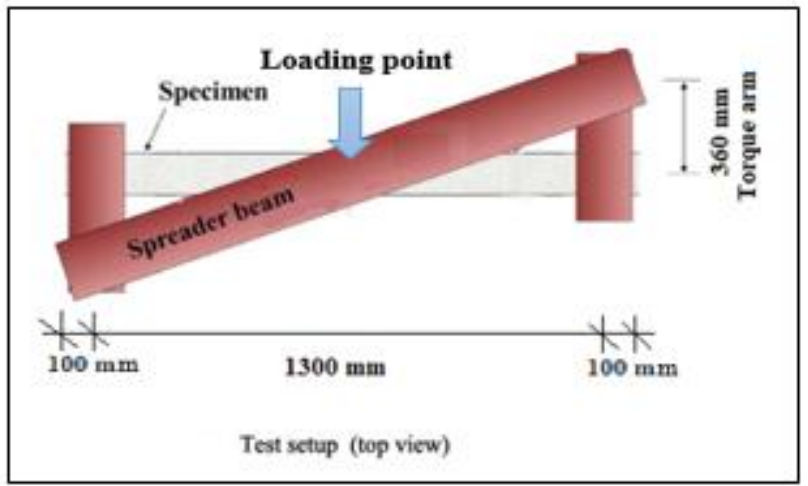

Fig. 4: Test Setup

\subsection{Test program}

The hydraulic universal testing machine having the amplitude of $(3000 \mathrm{kN})$, was wont (used) to check the beam specimens. In order to apply pure torsional moment to the specimen as indicated in Plate (1) and Figure (2), cantilevered torsion arms (of $360 \mathrm{~mm}$ ) with longitudinal axis of the beam were installed at both ends of the specimens which were loaded through a spreader beam by displacement control methods. The beams were placed in the machine on free supported rollers at each end with a clear span of $1300 \mathrm{~mm}$. A steel girder of $3 \mathrm{~m}$ length and $300 \mathrm{~mm}$ depth was applied to convey the loads from the center of the machine to the two arms of frame as shown in Figure (3), to fulfillment pure torsion. The angle of twist was rated by two digital gauges as shown in Plate (2), linked to the bottom fiber of the end of the beam on the right, and on the left was registered the uplift and down angle at a point $(30 \mathrm{~mm})$ from the center of the longitudinal axis of the beam to record the torsional angle of twist per unit length in radians. The beams had tested under pattern increasing increments of $1 \mathrm{kN}$ load, and the readings were acquired manually. The torque was increased regularly up to the point of failure of the beam.

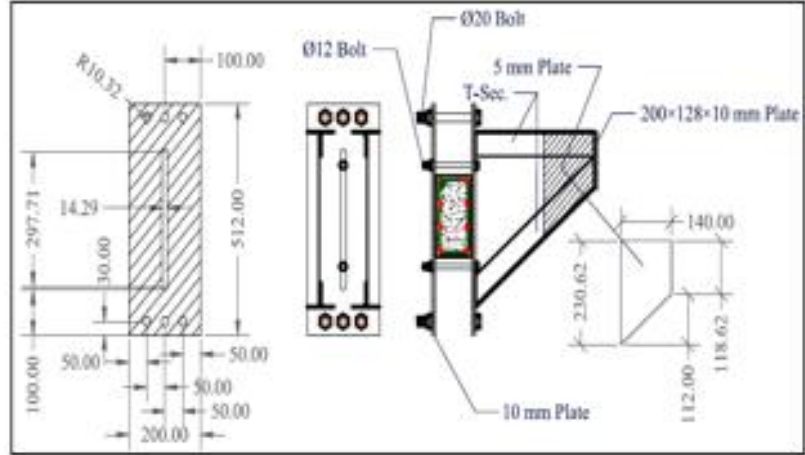

Fig.3: Details of frame of torque arm

\section{Results, and discussion}

For each group, the beams were designed to produce alike compressive strength in order to obtain evident contrast between the torsional strengths of NAC and RAC. However, there is a slight change in the compressive strength of concrete for each beam in the same group because the (w/c) is constant for each group. As expected, the mechanical properties of RAC are ordinarily less than those of the normal concrete, however the most significant effect was that the modulus of elasticity was lowest (18\%) for the RAC with replacement level of $100 \%$ compared to the NAC.

All are displayed in Table (6). The cracking torque (Tc), the ultimate torque $(\mathrm{Tu})$, and corresponding twist at cracking and ultimate stages $(\theta \mathrm{c}, \theta \mathrm{u})$, as well as longitudinal steel ratio $(\square l)$ and stirrups ratio $(\square v)$, are shown. For each group, the beams were designed to yield a comparable $\left(\mathrm{f}_{\mathrm{c}}\right.$ ) for evaluation between the torsional strengths of both NAC and RAC.

By observing the results, for all groups, we find that there is no significant difference in the beams containing 50\% RCA at cracking stage, but there is a slight difference that does not exceed $4 \%$ in the ultimate torque phase. The beams containing $100 \%$ RCA have (6.2, 8.3 and $12.5 \%$ ) variation rate for the three groups (N25, M45, and $\mathrm{H} 70$ ), respectively, in cracking stage. In the ultimate torsional moment stage, the rate of variation is $(7.7,6.9$ and $6.5 \%)$ for the groups (N25, M45, and H70), respectively. In general, the beams of the NAC produced higher ultimate torsional strength than the full replacement in RAC but did not exceed $7.7 \%$ in the same group of compressive strength. The percentage of deviation decreases in the stage of ultimate torque because it depends on the stirrups; and the longitudinal reinforcement of the section reaches the yielding point, and the concrete struts start to behave non-linearly.

Table 6: Summarized test results of beams

\begin{tabular}{|c|c|c|c|c|c|c|c|c|}
\hline GROUP & $\begin{array}{l}\text { Beam } \\
\text { Notation }\end{array}$ & $\begin{array}{l}\text { Compressive } \\
\text { strength } \\
f^{\prime} c(M P a)\end{array}$ & $\rho_{l} \%$ & $\rho_{v} \%$ & $\begin{array}{l}\text { Cracking torque } \\
\text { (Tc) (kN.m) }\end{array}$ & $\begin{array}{l}\text { Angle of twist } \\
(\theta c) \\
(\mathrm{rad} / \mathrm{m})\end{array}$ & $\begin{array}{l}\text { Ultimate torque } \\
(\mathrm{Tu})(\mathrm{kN.m})\end{array}$ & $\begin{array}{l}\text { Angle of twist } \\
(\theta u) \\
(\mathrm{rad} / \mathrm{m})\end{array}$ \\
\hline \multirow{3}{*}{$N 25$} & $25 \mathrm{NC}$ & 25 & 0.0157 & 0.0113 & 1.62 & 0.0053 & 4.68 & 0.1155 \\
\hline & $25 \mathrm{R} 50$ & 24 & 0.0157 & 0.0113 & 1.62 & 0.0057 & 4.68 & 0.12 \\
\hline & 25R100 & 22.3 & 0.0157 & 0.0113 & 1.52 & 0.0062 & 4.32 & 0.1155 \\
\hline \multirow{3}{*}{ M45 } & $45 \mathrm{NC}$ & 46 & 0.0157 & 0.0113 & 2.16 & 0.0044 & 5.22 & 0.1288 \\
\hline & $45 \mathrm{R} 50$ & 44 & 0.0157 & 0.0113 & 2.16 & 0.0048 & 5.04 & 0.1288 \\
\hline & 45R100 & 42 & 0.0157 & 0.0113 & 1.98 & 0.0053 & 4.86 & 0.1333 \\
\hline$H 70$ & $70 \mathrm{NC}$ & 70 & 0.0157 & 0.0113 & 2.88 & 0.004 & 5.58 & 0.1377 \\
\hline
\end{tabular}




\begin{tabular}{|llllllll}
$70 \mathrm{R} 50$ & 68 & 0.0157 & 0.0113 & 2.88 & 0.004 & 5.4 & 0.1422 \\
$70 \mathrm{R} 100$ & 60 & 0.0157 & 0.0113 & 2.52 & 0.0044 & 5.22 & 0.1422 \\
\hline
\end{tabular}

\subsection{Influence of compressive strength on torsional resistance}

It can be noticed that, the $\mathrm{H} 70$ group of beams is the strongest group according to the cracking and ultimate torsional moment, and is followed by the M45 group, after which comes the N25 group. The torque stage, up to the first crack, increases as the compressive strength of concrete $\left(f_{c}^{\prime}\right)$ increases because the torque of first crack depends largely on compressive strength of concrete since the effect of dimensions of the section are eliminated since it are fixed for all beams. The soft component in the RAC is the downiness aggregate-cement paste bond. Therefore, the compression strength of concrete effect effective factor in the resistance of the cracking and ultimate torque.

\subsection{Effecting of compressive strength on angle of twist}

The angle of twist is the two-dimensional deformation in the direction of torsional moment action. The angle of twist increases as the compressive strength of concrete increases. The result showed that, the angle of twist of the beam $70 \mathrm{NC}$ in the group $\mathrm{H} 70$ is greater than the beam notation $25 \mathrm{NC}$ in the group $\mathrm{N} 25$ by about $16.14 \%$ for NAC. The beam notation 70R100 in the group H70 is greater than that of the beam $25 \mathrm{R} 100$ in the group N25, which is about $18.64 \%$ for RAC.

The angle of twist (deformation) for the beams of RAC is more than NAC beams because the RAC has a lower elastic modulus, and the peak and ultimate strain of RAC is more than NAC [24].

\subsection{The failure mode}

Generally, the torque-twist conduct of RAC reinforcement beams is similar to that of NAC beams. The formation of the torsional crack for RAC is equal to or less than the magnitude of (Tc) of NAC. The value of first crack (Tc) is sensitive to the grade of the compressive strength of concrete used. At the stage of ultimate torque, the NAC is slightly greater than RAC due to the breakdown of concrete struts of RAC (aggregate-cement paste adhesion failure). Figures $(4,5$ and 6$)$ is a torque - twist curve for groups (N25, M45 and H70) respectively, which illustrates. The torsional behavior of three beams for each group that showed a similar approach in resisting the applied torque.

The failure patterns of the beams are shown in Plates (3, 4, and 5) for each mix group respectively. The failure manner of fully the beams presented a uniform skew bending failure. This was a principal torsion crack with an angle of inclination of around (43 to $48^{\circ}$ ) with the longitudinal axis of the beam. The failure mode was compatible with the beams of each mix group.

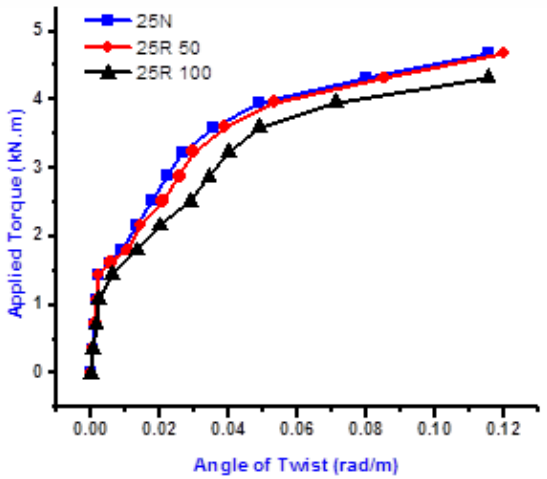

Fig. 4: Torque-twist behavior for group N25

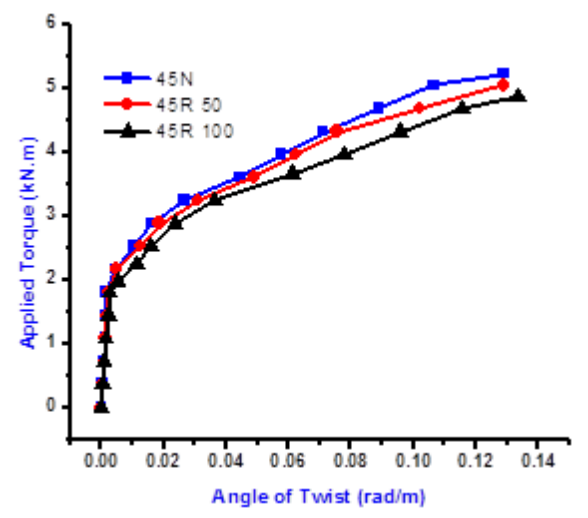

Fig. 5: Torque-twist behavior for group M45
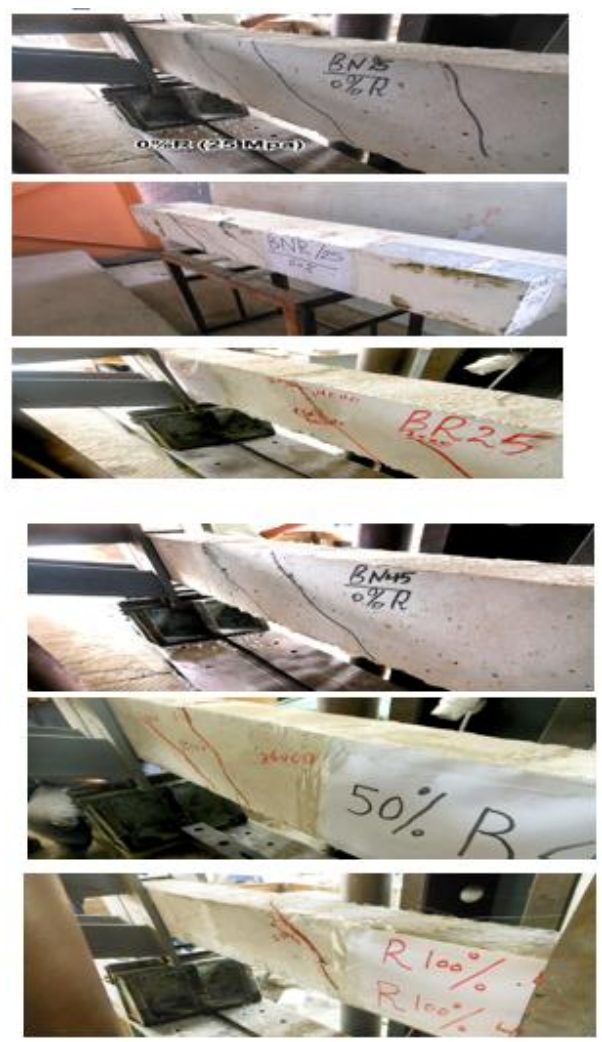

Figure 6: Experimental spice 


\section{Conclusions}

1- Water absorption of RCA is more than the water absorption of NCA due to the older mortar that adhered to the surface of aggregate.

2- The mechanical properties of RAC are ordinarily lower to those of normal concrete, but the most significant effect is that the modulus of elasticity was lowest, at about (18\%) for the RAC with a replacement level of $100 \%$, compared to the NAC.

3- Torsional strength of the concrete beams decreases with an increase in the proportion of replacement of NCA with RCA.

4- For all groups, there is no important difference among NAC and RAC50 beams in the cracking and ultimate torque.

5- Little differences of around $7.7 \%$ were observed between NAC and RAC100 beams in the torsional behavior for ultimate torque.

6- The compression strength of concrete has significant effect on the resistance of the cracking and ultimate torque.

7- The angle of twist for beams at cracking and failure increases with increase in the ratio of replacement of NCA with RCA, due to the RAC which has a lower elastic modulus, and the peak and ultimate strain of RAC which is more than NAC.

8- The failure mode in whole the beams appear skew bending failure. Generally, the torque-twist performance of RAC reinforcement beams are similar to that of NAC beams.Comparison of torsional behavior, (cracking and ultimate torque), crack patterns, failure modes of NAC and RAC beams, according to the above results, confirm that the employ of RAC in reinforced concrete beams is practically possible for torsional behavior.

\section{References}

[1] Kasai, Y., \& Fujii, T. "Demolition and reuse of concrete and masonry". Concrete International, Vol. 11, No. 3, (1989), pp.24-28.

[2] Rao, A., Jha, K. N., \& Misra, S. "Use of aggregates from recycled construction and demolition waste in concrete". Resources, conservation and Recycling, Vol. 50, No.1, (2007), pp.71-81.

[3] Hansen, T. C. "Recycling of Demolished Concrete and Mansory". RIREM Report l, 1994.

[4] Yagishita, F. (1994). "Behavior of reinforced concrete beams containing recycled coarse aggregate". Demolition and Reuse of Concrete and Masnry, pp. 331-342.

[5] Ryu, J. S. "An experimental study on the effect of recycled aggregate on concrete properties." Magazine of concrete research. Vol. 54, No. 1, (2002), pp. 7-12.

[6] Xiao J, Li J, Zhang Ch. Mechanical properties of recycled aggregate concrete under uniaxial loading. Cement Concrete Res. Vol. 35, No.6, (2005), pp. 1187-1194.

[7] González, B., \& Martínez, F. "Shear strength of concrete with recycled aggregates". In Ed.), Int. RILEM Conf. Use Recycl. Mater. Build. Struct., Barcelona, Spain, (2004), pp. 619-628.

[8] Choi, H. B.; Yi, C. K.; Cho, H. H.; and Kang, K. I., "Experimental Study on the Shear Strength of Recycled Aggregate Concrete Beams”, Magazine of Concrete Research, Vol. 62, No. 2, (2010), pp. 103-114.

[9] Schubert, Sandy, "Recycled aggregate concrete: experimental shear resistance of slabs without shear reinforcement." Engineering Structures. Vol. 41, (2012): pp. 490-497.

[10] Arezoumandi, M., Drury, J., Volz, J. S., \& Khayat, K. H. "Effect of Recycled Concrete Aggregate Replacement Level on Shear Strength of Reinforced Concrete Beams”. ACI Materials Journal, Vol. 112, No. 4, July-August (2015).
[11] Central Organization for Standardization and Quality Control; "Iraqi Standard Specification for the Portland Cement", Baghdad, Iraq. IQS 5, (1984).

[12] Iraqi Specification No. 45, "Natural Sources for Gravel that is Used in Concrete and Construction". Baghdad, (1984).

[13] American Society of Testing and Material (ASTM), "Standard Specification for Concrete Aggregates", ASTM C33-02, West Conshohocken, PA, (2002).

[14] Standard Specification for Chemical Admixtures for Concrete. ASTM-C494-05, American Society for Testing and Material, (2005).

[15] ASTM, ASTM. "C1240: Standard specification for silica fume used in cementitious mixtures." ASTM International, West Conshohoken, PA, USA (2014).

[16] ASTM, Standard C143-00, "Standard Test Method for Slump of Hydraulic Cement Concrete," ASTM International, West Conshohocken, PA.

[17] ACI 211.1-97, "Standard practice for selecting proportions for normal, heavy weight and mass concrete", ACI Manual of Concrete Practice, American Concrete Institute, Detroit, (1997).

[18] ASTM Designation C39-01 "Standard specification for testing method for compressive strength of cylindrical concrete specimens", 2001 Annual Book of ASTM Standards, American Society for Testing and Material, Philadelphia, Pennsylvania, Section 4, Vol. (4.02), (2001), pp 20-24.

[19] ASTM Designation C469-02 "Standard specification for testing method for static modulus of elasticity and poison's ratio of concrete in compression", 2002 Annual Book of ASTM Standards, American Society for Testing and Material, Philadelphia, Pennsylvania, Section 4, Vol. (4.02), (2002), pp 236-239.

[20] ASTM Designation C496-96 "Standard specification for splitting tensile strength of cylindrical concrete specimens", 1996 Annual Book of ASTM Standards, American Society for Testing and Material, Philadelphia, Pennsylvania, Section 4, Vol. (4.02), (1996), pp 1-4.

[21] ASTM Designation C78-02 "Standard specification for testing method for flexural strength of concrete (using simple beam with third-point loading)", 2002 Annual Book of ASTM Standards, American Society for Testing and Material, Philadelphia, Pennsylvania, Section 4, Vol. (4.02), (2002), pp 32-34.

[22] ACI Committee 318, "Building Code Requirements for Structural Concrete (ACI 318M-14) and Commentary (ACI 318RM-14)", American Concrete Institute, Michigan, USA, (2014), 519 pp.

[23] MacGregor, J. G. and Ghoneim, M. G., "Design for Torsion", ACI Structural Journal, Vol. (92), No. 2, March-April (1995), pp. 211218,

[24] Belén, G. F., Fernando, M. A., Diego, C. L., \& Sindy, S. P. "Stressstrain relationship in axial compression for concrete using recycled saturated coarse aggregate". Construction and Building materials, Vol. 25, No. 5, (2011), PP. 2335-2342. 